\title{
THE TANGANYIKA PLATEAU
}

The book ${ }^{1}$ which is under review is dedicated to the memory of the late Robert Codrington, C.M.G., who was administrator of North-Eastern Rhodesia for nearly ten years between 1898-1907, and who prior to that had been, on the selection of the writer of this review, placed in charge of a western district of Nyasaland, having served earlier still in the Bechuanaland Protectorate. Although the political lines of the Tanganyika Plateau and of North-Eastern Rhodesia had been previously laid down by the present writer, by Sir Alfred Sharpe, Joseph Thomson, and Mr. A. J. Swann (though the work of the latter lay for the most part farther to the north, and was subsequently sacrificed to Germany), to Mr. Codrington undoubtedly falls the credit for bringing all this region under effective control, and introducing a degree of law and order remarkable for Central Africa, and achieved with very little cost in men and money, being largely due to the strong personal character of himself and of those who served with him and under him, amongst whom must certainly be included the writers of this book, who are both of them servants of the British South Africa Company.

The inclusion of North-Eastern Rhodesia and the Tanganyika Plateau within the limits of the British Empire was perhaps first inspired by the earliest journeys of Dr. Livingstone, and by the explorations of the late Joseph Thomson and Consul Frederick Elton. It was next given an important impulse by Frederick Moir and John Moir, agents of the African Lakes Company, who together with their assistants partially constructed the Stevenson Road, and conveyed a

1 "The Great Platen of Northern Rhodecin: being wome Impressions of the Tengangila Platean," by Cullen Gooldsbarg and Hubert Sheane, with an Introduction by Sir Alfred Shape, K.C.M.G., C.B. 
steamer in sections from the north end of Lake Nyasa to the south end of Tanganyika in the year 1885 . This steamer was sent along the Nyasa-Tanganyika route on behalf of the London Missionary Society, whose agents established themselves at the south end of Tanganyika, when owing to Arab troubles and the possibility of international complications their presence on the eastern shores of that lake had become precarious. The result of this coming in of the White man as missionary and trader (and the traders of those days were lay missionaries) inevitably precipitated a quarrel with the Arab slave-traders. Livingstone had revealed to the world the devastation which was being caused by the raids of the Zanzibar Arabs, but his denunciations rather applied to the Manyema country and other regions to the west of Tanganyika. Although he was the first European after the early Portuguese explorers to enter any part of the Awemba country, and decidedly the first to see the south end of Tanganyika, he had not much to complain of in regard to the Arabs on the Tanganyika Plateau, because their raids in those days were held in check by the powerful Awemba people. Not that the circumstances of the Babisa, the Alungu or Amambwe, or other peoples of North-Eastern Rhodesia were much happier on this account; it only meant that they were raided instead by the Awemba, who sold them as slaves to the Arabs on Tanganyika or Nyasa.

But the brothers Moir, together with their colleague, Monteith Fotheringham, revolted against the Arab maltreatment of the North Nyasa peoples, and so precipitated a little unofficial war between Arabs and British, in which both Sir Frederick Lugard and Sir Alfred Sharpe distinguished themselves as volunteers. The war led to inconclusive results, and cut off all communications with the missionaries at the south end of Tanganyika, and this at a time when the Arabs of East Africa had risen against the Germans and Belgians. Consequently, in 1889, the reviewer, then British Consul at Moçambique, was obliged to negotiate a peace between Arab settlers and Scottish traders at the north end of Lake Nyasa and so reopen the route to Tanganyika. In view of the advance of the Germans it was necessary for the protection of 
British interests that all this region should then and there be placed under British protection, and numerous treaties having been made with the chiefs the British fiag was hoisted on the south and south-west coasts of Tanganyika in the summer of 1889 , and at the north end of that lake (by Mr. Swann) a few months afterwards. The late Cecil Rhodes associated himself with this undertaking, and was represented by Sir Alfred Sharpe, who concluded treaties on behalf of the British South Africa Company which supplemented those of Sir Harry Johnston made on behalf of the Foreign Office. Mr. Rhodes or his Company subsequently bore the expense of bringing all this region under administrative control down to the year 1895, when it was definitely transferred to the administration of the British South Africa Company. But the authors are in error (on p. 40) in stating that the sum thus expended totalled $\$ 750,000$. They have added a cypher, the expenditure in question having been only $\notin 75,000$, of which a considerable portion was repaid afterwards by the Imperial Government, whilst the balance was recovered by the Chartered Company through the sale of a small portion of its land to a subsidiary syndicate. Consequently, neither Mr. Rhodes nor his Company were obliged to make the preliminary financial sacrifices unconsciously attributed to them by the authors, though no doubt since 1895 they have administered this region with little profit to themselves, though with very great benefit to the indigenous peoples. North-Eastern Rhodesia has always remained connected to some extent with the Imperial Administration of Nyasaland, and its police has been furnished (at the cost of the Chartered Company) from that Protectorate. Therefore Sir Alfred Sharpe, who succeeded the present writer as the chief official in Nyasaland, has remained associated with the development of this region down to the present year, when he retired from his post as Governor. No fitter person could have been chosen to preface this interesting book than Sir Alfred Sharpe, for as regards treaty-making and exploration be played the leading part in the acquisition of NorthEastern Rhodesia, and so far as the scope of his journeys went, justified my ambitious title of "British Central 
Africa"; for had due effect been given to his work the British protectorate north of the Zambezi would not only bave included Nyasaland and Barotseland, but also much of what became subsequently the Belgian Congo; while if Lord Salisbury had not under pressure from the German Government abandoned the territory secured by treaty at the north end of Tanganyika, the British Central Africa Protectorate would have filled up completely the gap which now lies along the Cape-to-Cairo route.

A good deal of this history is given in the work under review, though one or two points have been corrected or supplied by the reviewer. The authors, however, rightly do not take up more than a small portion of their space with an historical survey, but apply themselves to a description of the Awemba people-the leading tribe on the Plateau-to the ethnology of North-Eastern Rhodesia, the life of the European in these regions, the results of mission work, the wild game, the trade prospects, and the fascinating scenery. Their treatment of the history, by the by, commences with a very interesting summary of the oral traditions and legends of the Awemba, who boast of having possessed a dynasty of Crocodile kings (chiefs of the crocodile totem, that is to say), which has numbered some nineteen rulers. The authors are probably right in arriving at the conclusion that the Awemba conquerors and their culture (and, I would add, their language) came from the north-north-west, from the Luba stock of Southern Congoland; the very word Ñandu or Ngandu, for crocodile, and the phrase Wena-hiandu, are of Congolese affinities (see my book on George Grenfell and the Congo, pp. 354, 564, 684). The Eastern Bantu word-root for crocodile is $N g$ ona or Ngwena, whereas the Gandu root can be traced right up through Congoland to the non-Bantu regions of the Central Sudan. In fact, Awemba conquest-and-culture was but one of the numerous waves occasioned by the Bushongo invasion and development of Central Congoland, though another ethnic element which has entered the NyasaTanganyika Plateau from the north and north-east is either Hima, from the direction of Uganda, or Nilotic, from the southeast of the Victoria Nyanza. To some extent all these 
elements have been combined in the Wemba (Bemba, Emba may be the real root) culture, just as they have equally joined in the formation of another remarkable South African people --the Zulu-Kafir.

Though the point is not emphasised by the authors, the reviewer can supply the assertion that the Itawa people referred to in the book (Tawa, Taba) speak a purer and more archaic dialect of Luwemba than that which is current on the Tanganyika Plateau, and the Amemba would seem to have resided for some time in the Itawa country before they invaded the regions farther south.

The Awemba ideas of religion are, as in the case of most Bantu peoples, compounded of three distinct elements. There is first of all God-Leza or Reza, a word which is sometimes applied as well to rain, thunder, and lightning, because these are the evidence and the manifestations of the existence of an indefinable Being in the sky. This belief probably goes back to the very dawn of religion, the actual emergence of Man from apehood. Hearing the thunder and seeing the lightning, and the effects of the lightning, he could not but imagine that there must live in the sky some entity of vastly greater power than himself or than any other animal on the face of the earth. With him were sometimes, but not always, associated the stars and the rain. The sun and the moon were often regarded as quite distinct beings, independent of or subservient to this God of the sky. The next element was the worship of ancestors, of the dead. After a time, in the development of the human mind, it seemed impossible for personages of great potency or influence on this earth to cease wholly to exist when the body died and decayed. There must be some impalpable essence or influence which remained after death, and which haunted the cavern, the hollow tree, or the grave where the body was deposited. Some thought that the spirit of the departed chieftain or father of the tribe went up to the sky and even associated itself in time with the utterer of thunder, the wielder of lightning, and the distributor of rain, so that the concept of "Cod the Father" thus came into existence. The third element in religion was witchcraft, which began simply with a control over medicine, 
poison, and disease, and gradually acquired a mystic, an empiric signification, and by means of this empiricism or this appeal to or control of impalpable forces, became a part of religion and connected with the influence of departed spirits or of the God of the sky, or of the lesser deities which came into existence through the attributing to rivers, trees, rocks, waterfalls, whirlpools, and volcanoes, a special entity or soul.

According to the authors of this book, Leza, the God of the Sky, still remains incomprehensible. He has not only been the creator of the sun, moon, and stars, but he is the author of life and the creator of man. After making a man and a woman he offered them two small bundles, in one of which was life and the other death. Unfortunately, the man chose the little bundle of death. Yet in the minds of the Awemba, Leza is more associated with life than with death. There are lesser gods-evil spirits, the allies of human wizards, who cause swift and violent deaths, and interrupt, as it were, the scheme of Leza, who himself brings about at the fit and proper time the gentle and delicate death of old age when the man's work is done.

So far as the Awemba people are concerned, the cult of Leza is outside their ordinary religion. There is no direct access to him by prayer or by sacrifices, which are made instead to Mulenga and other great tribal and ancestral spirits (Mulenga is no doubt akin to the Mulungu, the ancestral deity of the Eastern Bantu). The authors of this book, however, point out that the root Lungu approximates in these languages of the Tanganyika Plateau more closely to nature spirits than to the actual ghosts of ancestors which are called Mipashi. But there is often permutation in these religious ideas, and the ancestral spirit from being associated in burial with a cavern, a waterfall, a river, or a rock, subsequently becomes the nature spirit of that feature. The Milungu or nature spirits of the tribes of the Tanganyika Plateau are appealed to to send rain and fertilise the crops. It is believed that the ancestral spirits or Mipashi possess the power of temporary possession and of reincarnation. "In one of the rest-houses on the Stevenson Road lived a tame 
python, which waxed fat on the sour beer and fowls offered to it by the Winamwanga (a native tribe), who reverenced in it their ancestral spirit Chief, Kachinga. One day, alas ! the deity so far forgot himself as to dispute the ownership of the rest-house with a German cattle dealer . . . whereupon his hiss of disapproval was silenced by a charge of swan shot, and the worshippers of Kachinga saw him no more."

There are also evil spirits, the Viwanda, who are the souls of murderers, suicides, and sorcerers, that retain their malevolence after death. Some of these are reincarnated in the form of man-eating lions. But the Awemba also believe, like so many of the Congo peoples, in actual fairies-Viwawho are fantastic goblins living underneath trees or an anthill, which, however, at worst are only elfish and vexatious, and not evil or cruel. Many other details of religious beliefs and of the position and influence of the medicine-men, doctors, and sorcerers, are given in this book. These diviners and medicine-men are known by the term Shiruanga, a word which penetrates to the west coast of Lake Nyasa, where it is often applied to European doctors. The shi in this word is an honorific prefix derived from a widespread Bantu root meaning father (the Uganda se).

The totems of the Awemba and other tribes of the Plateau are described on pp. 93-4. The information is both new and interesting. The totems existing amongst the Awemba are the crocodile, elephant, lion, leopard, dog, goat, pig, fishand various kinds of fish-bee, bird, mouse, tortoise, frog, otter, duiker antelope, and ant; and also the rain, the millet grain, castor oil plant, mushroom, masuku fruit, banana, trees in general, grass, porridge, cooking-pot, drinking-bowl, and slag iron. Some of the names given to these totems are no longer the names in force in the current dialects, but belong to older, wider-spread Bantu terms more associated with the Congo Basin. The tribal prefix Bena, Wena (which I have explained in my book on George Grenfell and the Congo, is an old Bantu plural for "brothers," and not for children, as incorrectly stated by so many writers on Africa)

1 And not "masters," as stated by the anthors of this book. The root twe (Muine; plund, Baina-Bene) mean " nterme brother," 


\section{JOURNAL OF THE AFRICAN SOCLETY}

is particularly associated with totem clans. On the Tanganyika Plateau the law of exogamy is in force, and no sexual intercourse is allowed amongst members of the same totem. Indeed (say the authors), in olden times any such lapse was punished by death at the fiery stake.

Native litigiousness and the way in which the time of the White officials is spent in composing native quarrels are amusingly and sympathetically described on pp. 105-109. Amongst others, a typically complicated case is cited, "dealing with certain mythical goats which, some years before the Flood, apparently, were left in trust with a village headman. The genealogy of the goats is traced through centuries, each of the kids in successive generations having been, it would seem, personally known and cherished-the sole remaining survivor, which is none other than that same venerable ram whom we saw an hour ago, browsing off parched dhub grass in the shadow of a stunted bush, is produced and duly admired by the Court. And in the end a decision of a kind is arrived at-a decision which, more by good luck than good management, appears to satisfy all concerned."

Since civilised government was introduced into Tropical Africa the negro of almost all races has shown himself singularly efficient as a postman or mail-carrier. On the Tanganyika Plateau the native mail-carriers travel with unfailing regularity an average of twenty-five miles a day. Another pleasing feature in this book is the justice which is done to the results of mission teaching. Illustrations of native mission-trained clerks and telegraph operators are given, which should satisfy those who still continue to decry the general results of the teaching given by the Christian missionaries as productive of no permanent or practical improvement in the native. On the contrary, the evidence in this book, as in all other conscientious works on Africa well founded on direct personal observation, shows that the mission schools are creating an educated class of civil servant, of skilled artisan, telegraph operator, and agriculturist, who will be of inestimable advantage in the future development of Negro Africa. They should also realise that practically nothing of this kind comes from out of the teaching of Islam, and that 
Muhammadan training at most produces brave soldiers, sober, decently-clad shepherds, and agriculturists who work without method and with very little regard for the teachings of modern science. The authors touch ever so delicately on a point which most modern writers are afraid to deal with, at home as well as abroad; and that is the unreality of doctrinal religion, its lack of attraction to the negro mind as well as to the mind of the modern European. And they probably deplore, as do many other writers under different guises, the amount of time wasted by missionaries abroad as well as the clergy at home, in inculcating a worn-out theology, which has little practical application to the life problems of to-day, and the absorption of which by no means fortifies a weak moral character or guarantees stability in goodness. They point out how eager the native is to avail himself of the secular education given-and admirably given-at the mission schools, but how, having acquired this, he hurries away from any close adherence to religious observances. Yet, if I read this work aright and combine its findings with my own opinions, I think it may be said that whether the theology is cared for or not, the Sabbath strictly or loosely observed, Christian teaching does seem to build up a moral character in the negro, which is almost totally absent from the results of conversion to Islam. I have known personally so many negroes that were really good men and women, through and through, as the results of having been educated by missionaries, that I can never admit the failure of Christian missionary effort, though I am quite on the side of the lapsed in utterly refusing to recognise the institution of the Jewish Sabbath, in caring not two straws for unprovable dogmas, based themselves on the very fetishism and mysticism so often present in native negro religions-vestiges, in fact, of the childhood of the world, and not worth discussing seriously in the twentieth century. One has to take things as one finds them, and to admit that the theology of the Christian missionaries is at any rate harmless, whereas three-fourths of their work in moral and mental training will prove to have been of supreme advantage to the new peoples that are growing up in Africa under European supervision. 
It is difficult to do this work complete justice, even in such a lengthy review as that which I have undertaken. It should speak for itself. I have no desire to spare the readers of the A PRICAN JOURNAL the necessity of buying it by giving to them its facts and its theories in condensed form. It will certainly be noteworthy, and a permanent addition to the literature on Africa, and the photographs which illustrate it are well worthy of the text.

H. H. JOHNSTON. 